\title{
Younger Age of Presentation and Extraosseous Tumour in IgD Myelomatosis
}

\author{
J. R. HOBBS,* M.D., M.R.C.P., M.C.PATH. ; A. A. CORBETT, $\dagger$ M.B., CH.B.
}

Brit.med. F., 1969, 1, 412-414

Gummary : A study of 14 personal patients and 16 others $N$ in the literature shows that (1) IgD myelomatosis often presents at a significantly younger age than other forms of myelomatosis, and (2) during life extraosseous tumour can be detected in about two-thirds of these patients.

The IgD form represents $1.5 \%$ of myelomatosis and shows an increased incidence of osteolytic lesions, hypercalcaemia, and renal failure, together with heavy Bence Jones proteinuria $(90 \%$ type $\mathrm{L})$.

Like only Bence Jones myelomatosis, the IgD form seems to behave clinically in a more vicious manner.

\section{Introduction}

Since Rowe and Fahey (1965) described the first case of myelomatosis in which the paraprotein was identified as belonging to a new class of immunoglobulin, $\operatorname{IgD}$, clinical data have become available in a total of 30 such cases (see Table I). In the 14 patients known personally it seemed that the age of presentation was younger than in other forms of myelomatosis and that of ten the IgD tumour could be found growing out of the bones to form palpable masses-for example, around the ribs (see Fig. 1) -or even as deposits within the soft tissues such as the lymph nodes, spleen, liver, or even kidneys (see Fig. 2).

The available data have therefore been collected to see if these or other clinical features occur with greater frequency in IgD than in other classes of myelomatosis.

\section{Methods}

The criteria for accepting a diagnosis of myelomatosis, the methods of examining serum and urine, and the results in patients with IgG, IgA, and only Bence Jones myelomatosis are described elsewhere (Hobbs, 1969). The antiserum specific to IgD was the generous gift of Dr. D. Rowe.

In Table I heavy Bence Jones proteinuria infers over $100 \mathrm{mg}$./ $100 \mathrm{ml}$. and usually nearer $1 \mathrm{~g} . / 100 \mathrm{ml}$. Osteolytic lesions refer to the typical punched out radiological appearances of myelomatosis. Hypercalcaemia implies a serum calcium (corrected for the albumin level) above $5.5 \mathrm{mEq} / \mathrm{l}$. Renal failure was assumed to be present with a blood urea above $80 \mathrm{mg}$./ $100 \mathrm{ml}$. Extraosseous tumour applies to palpable masses around bones, clearly enlarged lymph nodes, or other soft-tissue masses. Hepatosplenomegaly or enlarged kidneys were accepted when shown to contain myelomatosis deposit. One patient (Case 29) who had plasma cell leukaemia is classed as having extraosseous tumour. The numbers at the bottom of Table I refer only to data which were clearly + or 0 .

\section{Results}

\section{Younger Age at Clinical Presentation}

Fig. 3 shows a histogram of the age distribution of the first 24 patients with IgD myelomatosis contrasted to scale with the

* Senior Lecturer in Chemical Pathology.

t Registrar in Chemical Pathology.

Royal Postgraduate Medical School, London W.12. frequency distribution found in $188 \mathrm{IgG}+94 \mathrm{IgA}$ cases (Hobbs, 1969a), and an early bulge is evident for IgD myelomatosis. This was tested by Kolmogorov's statistic, a $\chi^{2}$ test at the maximum difference of the cumulated frequency distribution. By $50-59$ years $66.7 \%$ of the 30 patients in Table I had been reached, whereas only $33.5 \%$ of the $282 \operatorname{IgG}+\operatorname{IgA}$ cases had been cumulated. This difference was highly significant $(\mathrm{P}<0.005)$.

TABlE I.-Data from 30 Patients with IgD Myelomatosis at the Time of Clinical Presentation

\begin{tabular}{|c|c|c|c|c|c|c|c|c|c|}
\hline$\dot{\mathrm{z}}$ & $\stackrel{8}{4}$ & $\stackrel{x}{凶}$ & 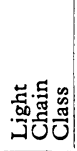 & 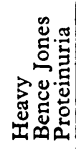 & 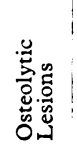 & 岁芯 & 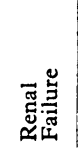 & 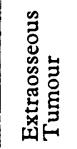 & Reference \\
\hline 1 & 57 & $M$ & L & + & - & - & - & - & Rowe and Fahey \\
\hline $\begin{array}{l}2 \\
3\end{array}$ & $\begin{array}{l}53 \\
55\end{array}$ & $\underset{\mathrm{F}}{\mathrm{M}}$ & $\underset{\mathrm{L}}{\mathrm{L}}$ & $\begin{array}{l}+ \\
+\end{array}$ & $\begin{array}{l}+ \\
+\end{array}$ & - & $\begin{array}{l}+ \\
+\end{array}$ & - & $\begin{array}{c}\text { Burtin et al. } \\
(1966)\end{array}$ \\
\hline $\begin{array}{l}3 \\
4\end{array}$ & 65 & $M$ & $\mathrm{~L}$ & + & - & - & - & - & Axelsson (1966) \\
\hline $\begin{array}{l}3 \\
6\end{array}$ & $\begin{array}{l}42 \\
42\end{array}$ & $\mathrm{~F}$ & $\mathrm{~L}$ & $\begin{array}{l}+ \\
+\end{array}$ & $\stackrel{+}{0}_{0} \quad-10$ & $\begin{array}{l}+ \\
+\end{array}$ & $\begin{array}{lll}+ \\
+\end{array}$ & $\begin{array}{l}t \\
t\end{array}$ & \\
\hline $\begin{array}{l}7 \\
8\end{array}$ & $\begin{array}{l}43 \\
53\end{array}$ & $M$ & $\mathrm{~L}$ & + & + & 0 & 0 & + & Hobbs et al. \\
\hline 9 & 56 & $M$ & $\mathrm{~L}$ & + & + & 0 & 0 & + & \\
\hline 10 & 44 & $M$ & $\mathrm{~L}$ & + & + & 0 & 0 & + & $\mathrm{P}$ \\
\hline & & & & & & & & & $\begin{array}{l}\text { R. B. Thompson } \\
\text { and A. R. Horler* }\end{array}$ \\
\hline 12 & $\begin{array}{l}62 \\
48\end{array}$ & $M$ & $\mathrm{~L}$ & + & + & + & + & + & C. L. Cope* \\
\hline 14 & 67 & $\mathrm{~F}$ & $\mathrm{~L}$ & $\mp$ & - & + & + & - & G. Blundell* \\
\hline $\begin{array}{l}15 \\
16\end{array}$ & $\begin{array}{l}74 \\
67\end{array}$ & $\begin{array}{l}M \\
M\end{array}$ & $\begin{array}{l}\mathrm{L} \\
\mathrm{L}\end{array}$ & $\begin{array}{l}+ \\
+\end{array}$ & + & $\begin{array}{l}0 \\
\pm\end{array}$ & $\begin{array}{l}0 \\
+\end{array}$ & $\begin{array}{l}0 \\
0\end{array}$ & $\begin{array}{l}\text { A. W. Walker* } \\
\text { P. H. Everall and }\end{array}$ \\
\hline 17 & 50 & $M$ & K & + & + & + & + & 0 & R. Penny* \\
\hline $\begin{array}{l}18 \\
19\end{array}$ & $\begin{array}{l}67 \\
45\end{array}$ & $\stackrel{M}{M}$ & $\begin{array}{l}\mathrm{L} \\
\mathrm{L}\end{array}$ & \pm & $\stackrel{+}{-}$ & $\stackrel{+}{-}$ & $\stackrel{+}{0}$ & \pm & $\begin{array}{l}\text { R. Penny* } \\
\text { Rogentine et al. }\end{array}$ \\
\hline 20 & 44 & F & $\mathrm{L}$ & + & 0 & - & 0 & - & Ventruto and \\
\hline 21 & 71 & $\mathbf{M}$ & ? & 0 & + & 0 & 0 & - & Zawadzki and \\
\hline 22 & 58 & $M$ & $\dot{K}$ & + & + & 0 & + & + & Rubini (1967) \\
\hline $\begin{array}{l}23 \\
24\end{array}$ & $\begin{array}{l}48 \\
55\end{array}$ & $\underset{\mathrm{F}}{\mathrm{M}}$ & $\mathrm{L}$ & $\begin{array}{l}t \\
+\end{array}$ & + & 0 & \pm & + & Masaki et al. (1967) \\
\hline 25 & 73 & $M$ & $\mathrm{~L}$ & $\mp$ & 0 & 0 & - & 0 & \}$_{(1967)}$ \\
\hline & 55 & $M$ & L & 0 & + & 0 & \pm & - & Wiedermann et al. \\
\hline 27 & 58 & F & $\mathbf{L}$ & + & 0 & 0 & - & 0 & Klemm et al. (1967) \\
\hline 28 & 55 & $\mathbf{M}$ & $\mathrm{K}$ & + & + & & + & 0 & $\begin{array}{l}\text { Dammacco and } \\
\text { Bonomo (1968) }\end{array}$ \\
\hline 29 & 69 & F & L & + & + & - & 0 & + & Ben-Bassat et al. \\
\hline 30 & 71 & $M$ & L & + & + & - & 0 & - & $\begin{array}{c}\text { Bert and Fontana } \\
(1968)\end{array}$ \\
\hline \multicolumn{2}{|c|}{ Total } & $\begin{aligned} 22 \mathrm{M} / \\
8 \mathrm{~F}\end{aligned}$ & $\begin{array}{c}3 \mathrm{~K} / \\
26 \mathrm{~L} \\
(90 \%)\end{array}$ & $\begin{array}{l}25 / 27 \\
(93 \%)\end{array}$ & $\begin{array}{l}20 / 26 \\
(77 \%)\end{array}$ & $\begin{array}{c}9 / 19 \\
(47 \%)\end{array}$ & $\begin{array}{l}12 / 23 \\
(52 \%)\end{array}$ & $\begin{array}{l}12 / 19 \\
(63 \%)\end{array}$ & \\
\hline
\end{tabular}

* Referrals to the M.R.C. myeloma trial centrc at Hammersmith Hospital.

The mean age for IgD patients at $57 \cdot 1$ years was similar to that for only Bence Jones patients ( 55.5 years) who also show a highly significant early bulge in frequency distribution with age (Hobbs, 1969).

\section{Extraosseous Tumour}

Figs. 1 and 2 show the two main types of extraosseous tumour growth: breaking out of a bone locally or truly within soft tissue. The photographs were kindly made available by Dr. G. Meachim, who carried out the necropsy in Case 10. In this patient Dr. H. T. Swan first drew our attention to extramedullary tumour. Table I shows that extraosseous tumour was detected during life in $63 \%$ of $\operatorname{IgD}$ patients where data were available. 


\section{Other Features of IgD Myelomatosis}

Table II summarizes the major features of IgD contrasted with the three commonest classes which account for IgG $53 \%$, IgA $22 \%$, and only Bence Jones $20 \%$ of myelomatosis.

The incidence of $\operatorname{IgD}$ myelomatosis was previously found to be $3 \%$ of proved myelomatosis (Hobbs et al., 1966), but this was probably an overestimate. To date only seven IgD patients

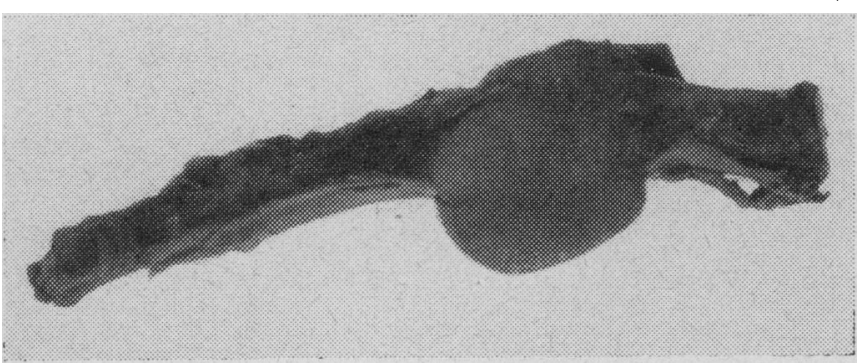

FIG. 1.-The IgD myeloma has broken out of the rib into the pleural tissues. In this patient (Case 10) both the pleura and outer wall of the chest were involved by numerous similar tumours. In other patients similar break-outs have occurred in the pelvis.

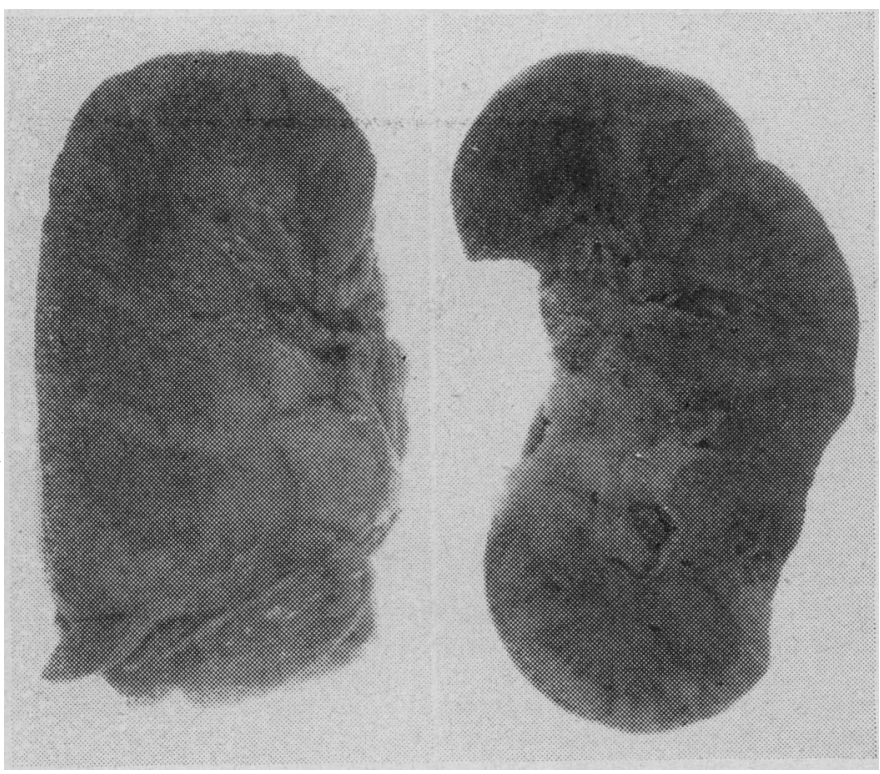

Fig. 2.-Both renal cortices are infiltrated with greyish IgD myeloma mottled with purplish patches. Similar involvement was seen in the spleen and liver in this patient (Case 10).

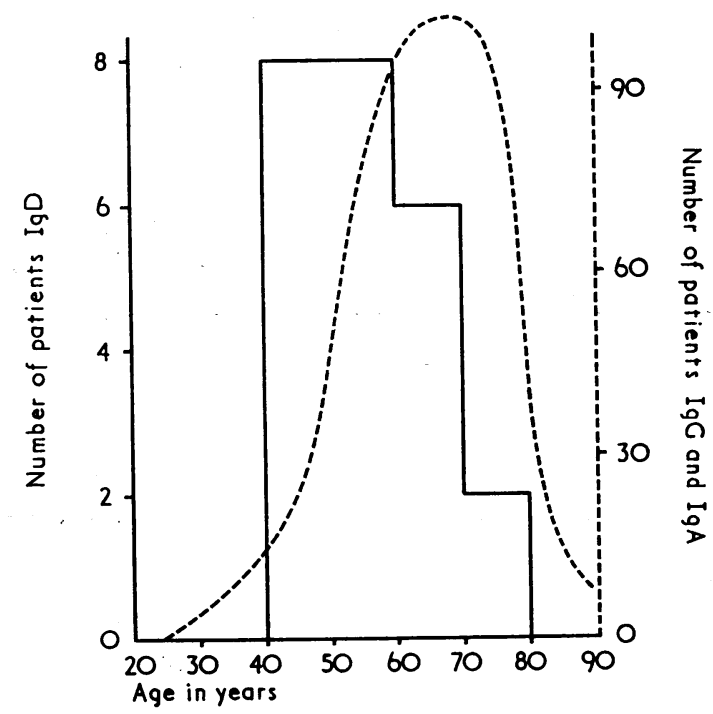

FIG. 3.-Histogram of age of presentation of IgD myeloma patients compared to scale with the frequency distribution for IgG and IgA myelomatosis. Note the excess of IgD patients presenting before age 59 years. have been found among our 456 consecutive cases, Bachmann (1965) reported 2 among 194 patients, and Zawadzki and Edwards (1967) 2 among 170 patients with definite myelomatosis, so that the true incidence is probably $1.5 \%$.

TABLE II.-Clinical Features of Myelomatosis at Presentation According to Immunochemical Class

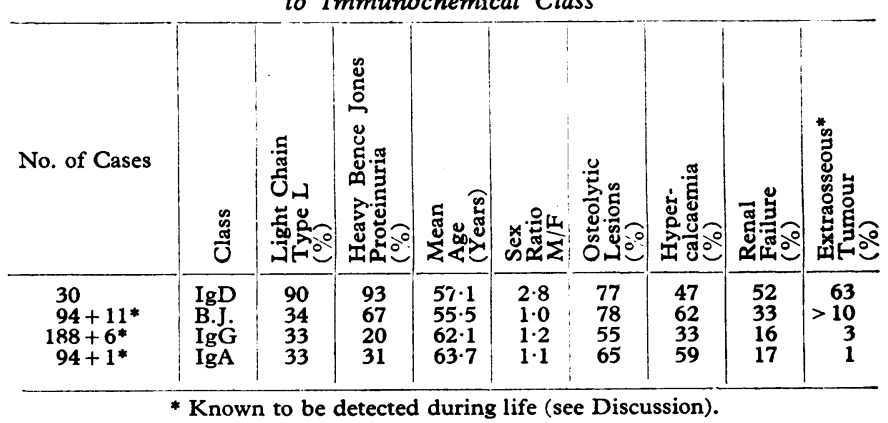

The sex ratio $2 \cdot 8 \mathrm{M}: 1 \mathrm{~F}$ is to date most unusual compared with other classes (see Table II). The incidence of osteolytic lesions is as high with only Bence Jones myelomatosis and is significantly greater than with IgG myelomatosis, as are also the high incidence of hypercalcaemia and renal failure. The other striking features are that $93 \%$ show heavy Bence Jones proteinuria and that the light chain class is type $\mathrm{L}$ in $90 \%$ as compared with $33 \%$ for other classes.

\section{Discussion}

This report establishes that presentation at younger ages is a feature of $\operatorname{IgD}$ myelomatosis compared with $\operatorname{IgA}$ and $\operatorname{IgG}$ myelomatosis. In this, together with the higher incidence of osteolytic lesions, hypercalcaemia, and renal failure, IgD myelomatosis is similar to only Bence Jones myelomatosis, as is also apparent from the high incidence of associated heavy Bence Jones proteinuria. The abortive parent of only Bence Jones myelomatosis is not known-that is, which heavy chain class has failed to be formed.

From the frequency of normal cells producing immunoglobulins of the different classes (Hobbs, 1968) it seems probable that the only Bence Jones parenthood includes all classes and probably only a very small fraction is derived from IgD. Evidence that only Bence Jones myelomatosis represents a dedifferentiated and more vicious form of myelomatosis is given elsewhere (Hobbs, 1969) and the present evidence suggests that IgD myelomatosis behaves similarly.

In this light extraosseous tumour growth might be expected. During life this is infrequently detected in other classes of myelomatosis ; Edwards and Zawadzki (1967) found only six such patients among 78 with myelomatosis. At necropsy it is known that extraosseous myeloma is found more frequently ; Innes and Newall (1961) reported 14 such cases among 45 necropsies, but in their overall series of 188 cases it appears only six were detected during life. Thus the $63 \%$ incidence of extraosseous tumour in IgD myelomatosis during life suggests this class differs significantly from the others. As regards only Bence Jones myelomatosis we have not collected adequate data in the 94 patients who have presented with the usual clinical picture of myelomatosis. On the other hand; another 11 only Bence Jones patients have presented as softtissue plasmacytoma. Only 1 out of $95 \operatorname{IgA}$ and 6 out of 204 IgG patients have had extramedullary presentations, so that, like IgD, the only Bence Jones cases seem to have a higher incidence of extraosseous tumour.

Finally, while 30 patients with $\operatorname{IgD}$ paraprotein have been shown to have myelomatosis, Bachmann (1965) records one such patient in whom no reticuloendothelial malignancy had been detected, though a bone marrow had not been examined. We have seen a man who died at 49 years of age from metastatic 
thyroid medullary carcinoma and who had in his serum $400 \mathrm{mg}$. of IgDL paraprotein. Bone marrow and radiological examination were negative. In co-operation with $\mathrm{Mr}$. Selwyn Taylor and Dr. E. D. Williams we could detect no arteriovenous difference in the plasma level of IgD across the circulation through a large mass of mediastinal carcinoma, some of which was successfully grown in tissue culture by Dr. P. J. L. Holt. Radioactive amino-acids were added, followed by carrier IgDL protein, but radioimmunoelectrophoresis did not show any IgD synthesis by the thyroid medullary carcinoma. It would thus seem that IgD, like other paraproteins, can sometimes have benign significance.

This work has been a by-product of the M.R.C. myeloma trial. I am grateful to all the participants (see Hobbs, 1969) and those colleagues mentioned in Table I and the text who have helped in the study of the patients. I am also indebted to Miss Felicity Henderson and Mrs. Urmila Patel for their assistance and to Professors I. D. P. Wootton and J. V. Dacie, and Dr. D. Galton for their encouragement.
REFERENCES

Axelsson, U. (1966). Scand. F. Haemat., 3, 123.

Bachmann, R. (1965). Acta med. scand., 178, 801.

Ben-Bassat, I., Frand, U. I., Isersky, C., and Ramot, B. (1968). Arch. intern. Med., 121, 361 .

Bert, G., and Fontana, F. (1968). Brit. med. F., 2, 117

Burtin, P., Guilbert, B., and Buffe, D. (1966). Clin. chim. Acta, 13, 675.

Dammacco, F., and Bonomo, L. (1968). Scand. F. Haemat., 5, 161.

Edwards, G. A., and Zawadzki, Z. A. (1967). Amer. F. Med., 43, 194.

Hobbs, J. R. (1968). Brit. F. Cancer. In press.

Hobbs, J. R. (1969). Brit. 手. Haemat. In press.

Hobbs, J. R., et al. (1966). Lancet, 2, 614 .

Innes, J., R., et Newall, J. (1961). Lancet, i, 239.

Klemm, D., Schubothe, H., Heimpel, H., and Kasemir, H. D. (1967). Klin. W Schr., 45, 590 .

Masaki, A., Danbara, C., Teramura, F., Sanada, I., Takata, T., and Shinozaki, K. (1967).' Acta haemat. jap., 30, 475 .

Rogentine, G. N., Rowe, D. S., Bradley, J., Waldmann, T. A., and Fahey, J. L." (1966).' F. clin.' Invest., 45,"1467.

Rowe, D. S., and Fahey, J. L. (1965). भ. exp. Med., 121, 171.

Spengler, G. A., Bütler, R., Pflugshaupt, R., Lopez, V., and Barandun, S. (1967). Schweiz. med. W schr., 97,170

Ventruto, V., and Quattrin, N. (1966). Haematologica, 51, 545.

Wiedermann, D., Wiedermann, B., Rádl, J., Skvařil, F., and Vacrman, J. P (1967), Schweiz, med. Wschr, 97, 207.

Zawadzki, Z. A., and Edwards, G. A. (1967). Amer. F. clin. Path., 48, 418

Zawadzki, Z. A., and Rubini, J. R. (1967). Arch. in:ern. Med., 119, 397.

\title{
Hypermagnesaemia in Presence of Magnesium Depletion in Acute-on-chronic Renal Failure
}

\author{
P. LIM,* M.B., B.CHIR., M.R.C.P. ; O. T. KHOO, $†$ M.D., F.R.C.P.ED., F.R.C.P.GLASG.
}

\begin{abstract}
Summary : A patient with renal failure developed hypermagnesaemia, with confusion, drowsiness, and dysarthria. Nevertheless, the dietary magnesium content was low, and investigation showed actual intracellular depletion of magnesium. The cause of this state is not known, though it is presumably connected with a failure to maintain the normal concentration gradient of magnesium across the cell wall. The clinical state and the serum magnesium level returned to normal after treatment with calcium gluconate.
\end{abstract}

\section{Introduction}

In renal failure hypermagnesaemia of ten develops in association with oliguric crisis (Hamburger, 1957 ; Takayasu et al., 1962). Severe reduction of glomerular filtration rate to less than 30 $\mathrm{ml} . / \mathrm{min}$. (Robinson et al., 1959), increased tissue catabolism and acidosis leading to shift of intracellular magnesium to the extracellular fluid (Nabarro et al., 1952; Martin and Jones, 1961), and the intake of magnesium-containing medication (Smith and Hammarsten, 1958) are responsible factors, jointly or severally. Very high values, in excess of $4 \mathrm{mEq} / 1$., are usually associated with a large intake of magnesium in the oliguric phase (Randall et al., 1964).

The case reported here is one of acute-on-chronic renal failure where the patient developed very high serum magnesium while on a restricted protein diet of low magnesium content. Magnesium-containing drugs were not given. A very interesting feature is the evidence of magnesium depletion while the patient was hypermagnesaemic.

* Lecturer, Clinical Medicine.

† Professor of Clinical Medicine.

University of Singapore, Singapore 3.

\section{Case Report}

A 57-year-old man, a known acromegalic, was admitted to the General Hospital, Singapore, on 4 August 1967. He gave a history of recurrent attacks of fever and chill associated with frequency of micturition, lethargy, and anorexia for one year, and a dull constant pain in the left loin associated with dysuria for three days. There had been no other past illness of note.

On examination, in addition to features of acromegaly (large protruding lower jaw, " main succulente," large tongue, thick coarse skin with multiple lipomata, and hepatomegaly) he was anaemic and sallow. An early diastolic murmur was heard at the left parasternal edge in the fourth and fifth intercostal spaces. There was collapsing pulse. Blood pressure was 130/60 and the left ventricle was enlarged. There was no evidence of congestive heart failure, and no tenderness in the left loin. The kidneys were not palpable. No abnormality was found in the respiratory and neurological systems. Fundi and visual fields were normal.

Serological tests for syphilis were negative. Blood urea was 240 mg. $/ 100 \mathrm{ml}$; creatinine clearance $1.6 \mathrm{ml} . / \mathrm{min}$.; $\mathrm{K} 5.8 \mathrm{mEq} / \mathrm{l}$.; $\mathrm{Mg} 2.9 \mathrm{mEq} / 1$. (normal $2.0 \pm 0.34$ (2 S.D.) $\mathrm{mEq} / \mathrm{l}$.) ; Ca $8.5 \mathrm{mg}$.) $100 \mathrm{ml}$. (normal $9.5 \pm 0.8 \mathrm{mg} . / 100 \mathrm{ml}$.); phosphate $13.7 \mathrm{mg} . /$ $100 \mathrm{ml}$. Both serum magnesium and serum calcium were estimated with atomic absorption spectrophotometry (Unicam SP 90). Urine examination showed the presence of numerous pus cells with albumin. Urine culture grew Escherichia coli. Glucose tolerance was mildly diabetic-104 mg. $/ 100 \mathrm{ml}$. (zero hour), $106 \mathrm{mg} . / 100 \mathrm{ml}$.

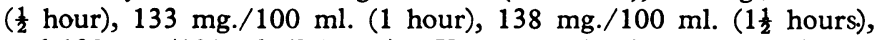
and $138 \mathrm{mg} . / 100 \mathrm{ml}$. ( 2 hours). $X$-ray examination of the abdomen showed vesical calculi and a calcified opacity in the left flank. No filling defects in the right renal pelvis were observed on retrograde pyelography, but stones were seen in the upper and lower calices of the left kidney. Chest $x$-ray examination showed a large heart with left ventricular enlargement and unfolding of aorta. Skull $x$-ray examination showed the presence of a large pituitary fossa and bony changes of acromegaly. Hand $x$-ray examination revealed typical acromegalic features-increase in length of fingers, accentua- 